INOBIS: Jurnal Inovasi Bisnis dan Manajemen Indonesia

Volume 1, Nomor 4, September 2018

Gilang Dwi Arta; Ni Made Purnami

\title{
Peran Mediasi Pemasaran Hijau Pada Pengaruh Persepsi Nilai Terhadap Repurchase Intension Pada Garden Villa Seminyak Bali
}

\author{
Gilang Dwi Arta ${ }^{1}$ \\ Ni Made Purnami ${ }^{2}$ \\ ${ }^{1,2}$ Fakultas Ekonomi dan Bisnis Universitas Udayana, Bali, Indonesia \\ email:madepurnami@unud.ac.id
}

\begin{abstract}
Abstrak
Penerapan pemasaran hijau suatu perusahaan berkaitan dengan tanggung jawab perusahaan mengenai kelestarian lingkungan. Penelitian ini bertujuan untuk mengetahui peran pemasaran hijau dalam memediasi pengaruh persepsi nilai terhadap repurchase intension. Penelitian ini dilakukan di Garden Villa Seminyak Bali dengan jumlah responden 140 orang. Responden penelitian adalah konsumen yang sudah pernah menginap di lebih dari satu malam di Garden Villa Seminyak Bali. Penelitian ini menggunakan teknik analisis jalur. Hasil penelitian menunjukkan bahwa 1) Persepsi nilai memiliki pengaruh positif dan signifikan terhadap pemasaran hijau; 2) Persepsi nilai memiliki pengaruh positif dan signifikan terhadap repurchase intension; 3) Pemasaran hijau memiliki pengaruh positif dan signifikan terhadap niat beli kembali; 4) Pemasaran hijau memediasi pengaruh persepsi nilai terhadap repurchase intension pada Garden Villa Seminyak Bali.
\end{abstract}

Kata kunci : pemasaran hijau, persepsi nilai, repurchase intension

\section{Pendahuluan}

Perkembangan industri yang terjadi saat ini baik secara langsung maupun tidak langsung telah memberikan dampak negatif bagi lingkungan. Untuk melindungi alam yang makin lama menunjukkan banyaknya kerusakan, sudah saatnya perusahaan mulai terlibat mencegah kerusakan alam yang terjadi. Polusi hasil industri ataupun polusi dari limbah hasil produk dapat disebabkan oleh beberapa jenis pencemar yaitu limbah industri, sisa insektisida, dan pembuangan sampah rumah tangga di aliran sungai.

Dalam era yang semakin peduli dengan kelestarian lingkungan, pada saat ini perusahaan mulai lebih memperhatikan pemasaran hijau (green marketing) (Chen, 2011). Meida et al. (2015) mendefinisikan pemasaran hijau sebagai: (1) Pengembangkan produk yang proses produksinya, penggunaannya atau pembuangannya tidak menimbulkan dampak berbahaya bagi lingkungan; (2) Mengembangkan produk dengan memberi dampak positif bagi lingkungan; (3) tidak sedikit perusahaan dari hasil penjualan produk tersebut sebagian digunakan untuk kepentingan organisasi lingkungan atau acara lingkungan. Produk hijau sebagai produk yang tidak akan mencemari bumi atau sumber daya alam yang dapat diperbaharui, produk memiliki keunggulan dalam mengurangi dampak lingkungan, namun juga memiliki kelemahan karena bahan yang digunakan serta proses teknologi yang digunakan membutuhkan biaya yang mahal (Arry et al., 2015). Perusahaan akan mengaplikasikan isu lingkungan dalam aktivitas pemasaran yang mereka lakukan, sehingga menimbulkan fenomena baru dalam dunia pemasaran berupa konsep pemasaran hijau. Pemasaran hijau menggabungkan tujuh elemen dari bauran pemasaran 
INOBIS: Jurnal Inovasi Bisnis dan Manajemen Indonesia

Volume 1, Nomor 4, September 2018

Gilang Dwi Arta; Ni Made Purnami

(marketing mix) dalam 7P yaitu: product, price, place, dan promotion, people (orang), physical evidence (fasilitas fisik), dan processs (proses) untuk menjual jasa yang ditawarkan dengan menggunakan keunggulan pemeliharaan lingkungan hidup yang dibentuk dari pengelolaan limbah, efisiensi energi, dan penekanan pelepasan emisi beracun (Sathiswaran et al., 2014).

Perubahan iklim yang sangat drastis disebabkan oleh lingkungan hijau yang terus dipangkas dan fungsinya digantikan (Anasti et al., 2013). Pemasaran hijau yang memiliki sistem yang baik dalam implementasinya akan memberikan kesadaran konsumen untuk melakukan pembelian produk hijau (Mahesh, 2013). Penerapan pemasaran hijau pada perusahaan harus diikuti dengan tanggung jawab kepada seluruh masyarakat mengenai kelestarian lingkungan melalui persepsi nilai dan pemasaran hijau yang sedang marak dilakukan oleh perusahaan dalam mendukung program go green. Kesadaran akan pentingnya suatu nilai pelayanan dapat mendorong seseorang untuk melakukan suatu perilaku pembelian (Rizki dan Ayu, 2014).

Persepsi nilai adalah nilai suatu produk atau jasa yang biasa ditaksirkan oleh konsumen menjadi suatu hal yang penting, karena apabila suatu produk tidak mampu menghasilkan nilai pada produk atau jasa tersebut, maka akan mudah diserang ataupun kalah dari pesaingnya. Nilai suatu poduk juga berkaitan erat dengan manfaat fungsional, praktek pembelian dan penggunaan merk dari produk tersebut (Artha et al, 2014). Dalam konteks villa, manfaat fungsional dapat dirasakan oleh konsumen pada saat praktek menggunakan jasa layanan dengan tampilan dekorasi, ornamen-ornamen interior villa yang menonjolkan kesan alami dari bahan kayu, bambu organik dan batok kelapa yang di kemas secara minimalis mengesankan kelestarian lingkungan.

Persepsi Nilai sangat penting untuk keberhasilan hubungan dengan konsumen, yang terdiri dari penilaian konsumen secara keseluruhan terhadap utilitas dari sebuah layanan berdasarkan persepsi dari apa yang diberikan atau manfaat yang diterima dan pengorbanan yang dilakukan. Nilai mencangkup tiga faktor utama (kualitas, harga dan kenyamanan), dimana kenyamanan adalah waktu dan usaha yang dikeluarkan oleh pelanggan (Hamed and Ghasem, 2014).

Pelaksanaan misi pemasaran hijau perusahaan dalam melakukan promosi melalui iklan yang sedang gencar dilakukan oleh banyak perusahaan saat ini. Fariddeddin (2013) menyatakan media sosial sebagai iklan merujuk pada internet berbasis layanan yang memungkinkan individu untuk membuat, berbagi dan mencari konten, serta untuk berkomunikasi dan berkolaborasi satu sama lain. Selain itu, social media marketing dipandang penting karena perkembangan kecanggihan teknologi saat ini dapat dimanfaatkan oleh para pengusaha untuk memasarkan produk mereka dalam meningkatkan niat beli kembali yang dilakukan konsumen. Meida et al. (2015) menyatakan niat beli kembali adalah kecenderungan konsumen untuk membeli ulang suatu merek atau mengambil tindakan yang berhubungan dengan pembelian yang diukur dengan tingkat kemungkinan konsumen melakukan pembelian untuk mengukur kontribusi konsumen dimasa yang akan datang pada sebuah merk.

Salah satu industri yang menghasilkan polusi saat ini adalah industri villa. Industri villa secara langsung ataupun tidak langsung menghasilkan polusi dan limbah yang berbahaya bagi lingkungan. Polusi secara tidak langsung oleh industri villa dihasilkan dari asap ruangan dapur dan polusi limbah pembuangan yang dihasilkan. Kesadaran masyarakat dunia akan pentingnya pelestarian lingkungan semestinya mendorong setiap industri pariwisata khususnya villa untuk menerapkan sistem pelayanan yang ramah lingkungan (go green) (Ashar, 2014). Kesadaran tersebut didasarkan pada sikap yang memandang pentingnya pelestarian lingkungan, dengan mengadopsi pemasaran hijau untuk semua kegiatan yang dirancang oleh perusahaan dalam 
INOBIS: Jurnal Inovasi Bisnis dan Manajemen Indonesia

Volume 1, Nomor 4, September 2018

Gilang Dwi Arta; Ni Made Purnami

rangka memenuhi kebutuhan manusia dengan mengurangi dampak yang merugikan bagi lingkungan. Fariddeddin (2013) mendefinisikan Pemasaran Hijau sebagai pemasaran yang mendukung lingkungan dengan menciptakan keuntungan terhadap lingkungan, hal ini didasarkan oleh apa yang konsumen harapkan.

Akomodasi pariwisata sejenis villa sangat diminati oleh wisatawan yang berkunjung ke Bali, dikarenakan villa memiliki suatu kelebihan dalam memberikan pelayanan melalui private service dan suasana yang mendukung dengan menampilkan sistem go green yang secara tidak langsung mengajarkan konsumen untuk hidup dengan mencintai lingkungan sekitarnya. Meningkatnya komitmen global terhadap lingkungan ini meniscayakan perusahaan untuk mengadopsi praktek-praktek pemasaran baru yang lebih ramah lingkungan. Bukan hanya karena setiap perusahaan harus bertumbuh dengan mengadopsi nilai-nilai yang diinginkan pelanggan, tetapi juga karena pelestarian lingkungan merupakan tanggung jawab sosial yang melekat pada diri setiap individu di dunia (Fariddeddin, 2013).

Mantra (2008) menyatakan akomodasi dengan tipe villa biasanya lebih disukai oleh wisatawan yang ingin berbulan madu, berlibur, bersama keluarga, maupun wisatawan yang menginginkan suasan yang lebih privat dan nyaman. Garden Villa Seminyak Bali yang beralamat di jalan Pura Telaga Waja No.168x Seminyak memiliki target pasar wisatawan domestik maupun asing yang membutuhkan private service, selain itu juga untuk melihat semakin pesatnya perkembangan dunia bisnis pariwisata di Indonesia pada umumnya dan Bali pada khususnya dengan memberikan pelayanan yang mengutamakan privasi, kenyamanan dan kemewahan dengan menawarkan tampilan dekorasi, ornamen-ornamen interior villa yang menonjolkan kesan alami dari bahan kayu, bambu organik dan batok kelapa yang di kemas secara minimalis mengesankan kelestarian lingkungan, kolam renang pribadi dengan hamparan taman yang luas dengan suasana yang tenang sehingga mengesankan gaya hidup back to nature.

Konsumen Indonesia saat ini masih akan memikirkan keuntungan apa yang akan didapatkan oleh konsumen tersebut saat memutuskan untuk terlibat dalam program hijau perusahaan tersebut (Setyo, 2011). Perusahaan dituntut untuk menjadi perusahaan hijau, menjalankan bisnis secara hijau dengan praktek pemasaran hijau sehingga memunculkan manfaat atau menanamkan niat beli kembali dimata konsumen.

\section{Landasan Teori dan Pengembangan Hipotesis}

The American Marketing Associate (AMA) mendefinisikan Green marketing is the marketing of products that are presumed to be environmentally safe. sebagai suatu proses pemasaran produk-produk yang diasumsikan aman terhadap lingkungan. Muhammad et al. (2011) mendefinisikan pemasaran hijau sebagai aplikasi dari alat pemasaran untuk memfasilitasi perubahan yang memberikan kepuasan organisasi dan tujuan individual dalam melakukan pemeliharaan, perlindungan, dan konservasi pada lingkungan fisik.

Grant (2007) menyatakan tujuan pemasaran hijau dibagi menjadi 3 tahapan, yaitu: 1) Green; 2) Greener dan 3) Greenest. Pemasaran hijau dapat memberikan manfaat, antara lain: 1) menghasilkan produk yang ramah lingkungan; 2) para produsen dan pemasang iklan mengembangkan produk yang mereka upayakan untuk memenuhi keinginan masyarakat yang peduli akan lingkungan; dan 3) Inovasi. Pemasaran hijau yang dilakukan oleh perusahaan memiliki dampak positif bagi perusahaan, antara lain : meningkatnya penjualan, memperbaiki 
INOBIS: Jurnal Inovasi Bisnis dan Manajemen Indonesia

Volume 1, Nomor 4, September 2018

Gilang Dwi Arta; Ni Made Purnami

umpan balik dari pelanggan, lebih dekat kepada pelanggan, mempertinggi kemampuan bersaing, memperbaiki citra perusahaan (Payne, 2000).

Pemasaran hijau merupakan konsep yang makin menarik bagi akademisi, praktisi, pembuat aturan publik, konsumen serta masyarakat yang peduli terhadap lingkungan. Alasan mengapa konsep ini menjadi sangat penting untuk diaplikasikan oleh perusahaan merupakan alasan sederhana yang sudah diketahui sejak dahulu, yaitu keterbatasan sumberdaya (Ottman, 2006:112). Dalam literatur ekonomi dinyatakan, bahwa ilmu ekonomi adalah ilmu yang mempelajari bagaimana manusia memenuhi kebutuhan dan keinginannya dengan alat pemenuhan kebutuhan atau sumber daya yang terbatas. Sumberdaya yang ada didunia, baik sumberdaya alam ataupun bukan, jumlahnya terbatas. Eksploitasi sumberdaya yang semena-mena dapat menyebabkan kerusakan lingkungan yang pada akhirnya menurunkan kesejahteraan konsumen dan masyarakat. Melalui konsen pemasaran hijau akan diperoleh manfaat secara langsung Ottman (2006:126): 1) Menghasilkan produk yang ramah lingkungan dan 2) Para produsen dan pemasang iklan mengembangkan produk yang mereka upayakan untuk memenuhi keinginan masyarakat yang peduli akan lingkungan

Persepsi nilai didefinisi sebagai penilaian konsumen secara keseluruhan terhadap manfaat jasa berdasarkan pada penilaian konsumen mengenai keuntungan yang diperoleh dari produk hijau dan biaya atau pengorbanan untuk mendapatkan dan menggunakan produk hijau tersebut. Persepsi nilai adalah nilai yang diterima konsumen terhadap suatu jasa yang merupakan trade off antara benefit yang diterima suatu produk yang diwujudkan dalam perceived quality dan perceived sacrifice yang harus dilakukan untuk memperoleh barang tersebut (Hamed and Ghasem, 2014).

Persepsi nilai adalah suatu penilaian pelanggan tentang manfaat yang didapat dari mengkonsumsi produk hijau secara keseluruhan. Penilaian keseluruhan konsumen dari kegunaan produk berdasarkan apa yang diberikan untuk produk tersebut dan apa yang akan didapatkan untuk memenuhi harapannya sebagai nilai yang dirasakan. Chen and Chang (2012) dalam (Hamed and Ghasem, 2014), mendefinisikan persepsi nilai sebagai penilaian menyeluruh konsumen terhadap seluruh manfaat yang diterima dan apa yang dikorbankan berdasarkan pada hasrat mengenai lingkungan.

Niat beli kembali (repurchase intension) adalah kecenderungan untuk membeli kembali sebuah merek dan secara umum berdasarkan kesesuaian antara motif pembelian dengan atribut atau karakteristikdari merek yang dapat dipertimbangkan (Belch, 2007:69). Busler (2007), niat beli kembali dapat diukur melalui dimensi likely yakni rencana pembelian kembali konsumen terhadap suatu produk, definitely would mengacu kepada kepastian konsumen dalam suatu produk, dan probable mengacu pada kemungkinan konsumen dalam membeli kembali suatu produk. Fariddeddin (2013) niat beli kembali adalah sebagai berikut: "Penggunaan atau pembelian berkelanjutan dari perhatian yang merupakan titik tolak bagi timbulnya hasrat (desire) untuk melakukan suatu kegiatan yang diharapkan komunikator". Sementara itu, repurchase intension menurut Felix (2015) adalah: "Keinginan yang kuat gairah kecendrungan hati yang sangat tinggi untuk mendapatkan kembali sesuatu dengan cara pengorbanan, mendapatkan sesuatu dengan membayarkan uang".

Sathiswaran et al., (2014) menemukan persepsi nilai yang dirasakan oleh konsumen mempunyai dampak positif terhadap pemasaran hijau. Hasil penelitian ini didukung oleh Felix (2015) yang menyatakan perusahaan yang mampu memberikan persepsi nilai positif dimata konsumen akan memberikan dampak positif pula terhadap penerapan strategi pemasaran hijau. 
INOBIS: Jurnal Inovasi Bisnis dan Manajemen Indonesia

Volume 1, Nomor 4, September 2018

Gilang Dwi Arta; Ni Made Purnami

Artha et al. (2014) menyatakan persepsi nilai sebagai salah satu faktor yang memiliki pengaruh positif pada penerapan pemasaran hijau sebagai strategi pemasaran. Berdasarkan pemahaman tersebut dapat dirumuskan hipotesis.

Persepsi nilai yang dinilai konsumen dapat memberikan dampak positif terhadap niat beli kembali (Meida et al., 2015). Artha et al. (2014) membuktikan hal yang sama niat beli kembali akan terwujud melalui peran positif dari persepsi nilai yang dipasarkan perusahaan. Sathiswaran et al. (2014) membuktikan hal yang sama dalam penelitiannya bahwa green reperceived value mampu meningkatkan nilai perusahaan sehingga memiliki dampak positif pada niat beli kembali. Berdasarkan hasil penelitian tersebut, diajukan hipotesis.

Pemasaran hijau adalah pondasi perusahaan yang dapat memberikan pengaruh positif terhadap niat beli kembali (Danny, 2014). Meida et al. (2015) menyatakan bahwa peran pemasaran hijau memberikan peluang yang baik dalam meningkatkan niat beli kembali. Fariddeddin (2013) menyatakan hal yang sama pemasaran dengan pemasaran hijau akan memberikan pengaruh positif pada niat beli kembali. Berdasarkan hasil penelitian tersebut, diajukan hipotesis.

Pemasaran hijau yang diterapkan perusahaan sangat dipengaruhi oleh persepsi nilai yang dirasakan konsumen pada saat menggunakan atau mengkonsumsi produk berdasarkan pemasaran hijau sebagai faktor pendukung (Meida et al., 2015). Sathiswaran et al. (2014) menyatakan membuktikan hal yang sama dengan adanya konsep pemasaran hijau mampu memberikan pengaruh positif hubungan persepsi nilai dengan niat beli kembali. Fariddeddin (2013) menemukan hal yang sama strategi pemasaran hijau akan meningkatkan pengaruh positif persepsi nilai terhadap niat beli kembali. Berdasarkan hasil penelitian tersebut, diajukan hipotesis.

$\mathrm{H}_{1}$ : persepsi nilai berpengaruh positif terhadap pemasaran hijau

$\mathrm{H}_{2}$ : persepsi nilai berpengaruh positif terhadap repurchase intension.

$\mathrm{H}_{3}$ : pemasaran hijau berpengaruh positif terhadap repurchase intension

$\mathrm{H}_{4}$ : pemasaran hijau memediasi pengaruh persepsi nilai terhadap repurchase intension

Berdasarkan penelusuran kajian pustaka dan hasil-hasil penelitian terdahulu maka model penelitian dapat digambarkan seperti Gambar 1.

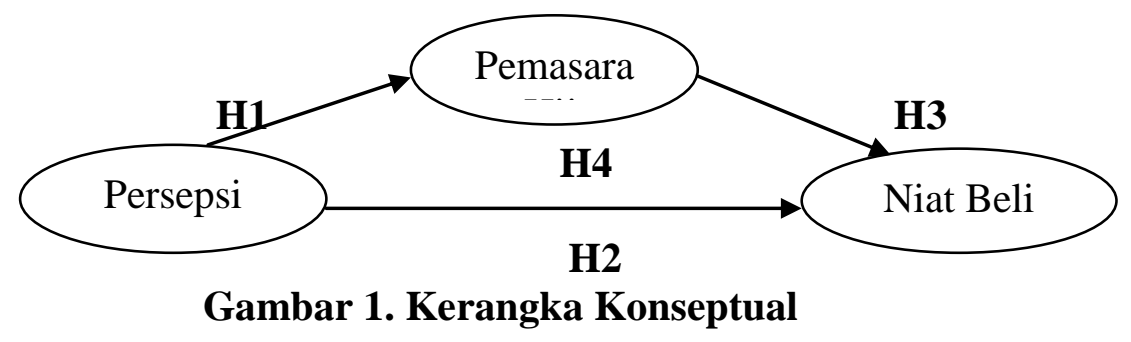

\section{Metode Penelitian}

Penelitian dilakukan di Garden Villa Seminyak Bali berada di lokasi utama di Jl. Pura Telaga Waja No.168x Petitenget, Seminyak, Bali. Akomodasi ini menawarkan kolam renang outdoor dan Wifi gratis, mengutamakan privasi, kenyamanan dan kemewahan dengan menawarkan tampilan dekorasi, ornamen-ornamen interior villa yang menonjolkan kesan alami 
INOBIS: Jurnal Inovasi Bisnis dan Manajemen Indonesia

Volume 1, Nomor 4, September 2018

Gilang Dwi Arta; Ni Made Purnami

berbahan kayu, bambu dan batok kelapa yang di kemas secara minimalis mengesankan kelestarian lingkungan sehingga mengesankan gaya hidup back to nature.

Populasi merupakan kumpulan dari semua elemen yang memiliki sejumlah karakteristik umum, terdiri atas himpunan untuk tujuan penelitian pemasaran (Malhotra, 2008:164). Dalam penelitian ini yang menjadi populasi adalah konsumen yang sudah pernah menginap di Garden Villa Seminyak Bali. Jumlah sampel yang dipergunakan dalam penelitian ini adalah 140 responden. Sampel diambil menggunakan purposive sampling yaitu teknik pengambilan sampel dimana pengambilan sampel disesuaikan dengan kriteria yang telah ditentukan peneliti. Data yang dikumpulkan dalam penelitian ini menggunakan kuisioner.

Pengujian Instrumen Penelitian dilakukan dengan menggunakan ujia validitas dan uji reabilitas. Sebuah instrumen dikatakan valid jika mampu mengukur apa yang seharusnya diukur, dan dapat mengungkap data dari variabel yang diteliti secara tepat. Syarat minimum untuk dianggap memenuhi syarat adalah kalau $r=0,3$ ”. Jadi kalau korelasi antara butir skor dengan skor total kurang dari 0,3 maka butir dalam instrumen tersebut dinyatakan tidak valid. Uji reabilitas bertujuan untuk mencari tahu sejauh mana kosistensi alat ukur yang digunakan, sehingga bila alat ukur tesebut digunakan kembali untuk meneliti obyek yang sama dan dengan teknik yang sama pula walaupun waktunya berbeda, maka hasil yang akan diperoleh adalah sama. Nilai suatu instrumen dikatakan reliabel bila nilai Alpha Cronbach $\geq 0,6$.

Teknik analisis data yang digunakan dalam penelitian ini adalah uji asumsi klasik dan teknik analisis jalur (path analysis). Analisis jalur merupakan perluasan dari analisis regresi linier berganda, untuk menaksir hubungan kausalitas antar variabel yang berjenjang berdasarkan teori (Utama, 2009:135).

\section{Hasil dan Pembahasan}

Karakteristik responden menunjukkan bahwa berdasarkan dari jenis kelamin jumlah pelanggan laki-laki sebanyak 93 orang atau 67 persen dan perempuan sebanyak 47 orang atau 33 persen. Hal ini menunjukkan bahwa jumlah pelanggan lebih didominasi oleh pihak laki-laki, mengingat laki-laki sebagai kepala keluarga sering mengajak keluarganya untuk berlibur menjari kenyaman dan prevasi di villa. Berdasarkan usia, jumlah pelanggan terbanyak yaitu yang berumur $>45-55$ tahun sebanyak 69 orang atau 50 persen sedangkan jumlah pelanggan yang paling sedikit yakni yang berumur > 55 tahun yaitu sebanyak 5 orang atau 4 persen. Berdasarkan pernah berkunjung, dapat diketahui sebagian besar menjadi pelanggan kurang lebih sudah menginap selama 3 malam yaitu sebanyak 60 orang atau 43 persen hal tersebut didukung dengan suasana yang diberikan oleh Garden Villa Seminyak Bali selalu mengutamakan kepuasan dan up to date. Berdasarkan penghasilan, dapat diketahui sebagian besar berpenghasilan $>\mathrm{Rp}$ 15.000.000 yaitu sebanyak 99 orang atau 81 persen, mengingat harga setiap pelayanan dari Garden Villa Seminyak Bali relatif mahal sehingga membutuhkan biaya cukup banyak.

\section{Uji Instrumen Penelitian}

Pengujian instrumen (uji validitas dan uji reliabilitas) dihitung menggunakan program Statistic Package for Social Science (SPSS) versi 15.0 for window, adapun hasilnya menunjukkan nilai korelasi setiap instrumen penelitian lebih besar dari 0,3 maka dapat disimpulkan bahwa 
INOBIS: Jurnal Inovasi Bisnis dan Manajemen Indonesia

Volume 1, Nomor 4, September 2018

Gilang Dwi Arta; Ni Made Purnami

instrumen penelitian dalam penelitian ini adalah valid dan dapat dipakai untuk melakukan pengumpulan data penelitian. Hasil pengujian Validitas ditunjukkan pada Tabel 1.

Tabel 4.1 Hasil Uji Validitas Instrumen

\begin{tabular}{|c|c|c|c|c|}
\hline No & Variabel & $\begin{array}{l}\text { Item } \\
\text { Pernyataan }\end{array}$ & $\begin{array}{l}\text { Koefisien } \\
\text { Korelasi }\end{array}$ & Keterangan \\
\hline \multirow{3}{*}{1} & \multirow{3}{*}{ Persepsi nilai $(\mathrm{X})$} & $\mathrm{X}_{1.1}$ & 0,788 & Valid \\
\hline & & $\mathrm{X}_{1.2}$ & 0,878 & Valid \\
\hline & & $\mathrm{X}_{1.3}$ & 0,842 & Valid \\
\hline \multirow{7}{*}{2} & \multirow{7}{*}{ Pemasaran hijau $\left(\mathrm{Y}_{1}\right)$} & $\mathrm{M}_{.1}$ & 0,794 & Valid \\
\hline & & $\mathrm{M}_{.2}$ & 0,702 & Valid \\
\hline & & $\mathrm{M}_{3}$ & 0,803 & Valid \\
\hline & & $\mathrm{M}_{4}$ & 0,836 & Valid \\
\hline & & $\mathrm{M}_{.5}$ & 0,766 & Valid \\
\hline & & $\mathrm{M}_{6}$ & 0,878 & Valid \\
\hline & & $\mathrm{M}_{.7}$ & 0,814 & Valid \\
\hline \multirow{4}{*}{3} & \multirow{4}{*}{ Repurchase Intension $\left(\mathrm{Y}_{2}\right)$} & $Y_{.1}$ & 0,917 & Valid \\
\hline & & $\mathrm{Y}_{.2}$ & 0,895 & Valid \\
\hline & & $\mathrm{Y}_{.3}$ & 0,690 & Valid \\
\hline & & $Y_{.1}$ & 0,889 & Valid \\
\hline
\end{tabular}

Sumber : Hasil pengolahan data penelitian, 2017

Hasil Uji reliabilitas menunjukkan bahwa seluruh instrumen di atas adalah reliabel karena memiliki nilai croanbach's alpha hitung lebih besar dari 0,60 sehingga kuisioner dalam penelitian ini layak dipakai untuk mengumpulkan data dalam pengujian hipotesis. Hasil pengujian reliabilitas ditunjukkan pada Tabel 2.

Tabel 2. Hasil Uji Reliabilitas Instrumen

\begin{tabular}{llcl}
\hline No & \multicolumn{1}{c}{ Variabel } & $\begin{array}{c}\text { r alpha } \\
\text { hitung }\end{array}$ & Keterangan \\
\hline 1 & Persepsi nilai $(\mathrm{X})$ & 0,768 & Reliabel \\
\hline 2 & Pemasaran hijau $\left(\mathrm{Y}_{1}\right)$ & 0,903 & Reliabel \\
\hline 3 & Repurchase Intension $\left(\mathrm{Y}_{2}\right)$ & 0,871 & Reliabel \\
\hline
\end{tabular}

Sumber : Hasil pengolahan data penelitian, 2017

\section{Uji Asumsi Klasik}

Uji asumsi klasik dilakukan untuk menguji kelayakan model yang dibuat sebelum digunakan untuk memprediksi, adapun uji asumsi klasik meliputi: uji normalitas, uji multikolinearitas dan uji heteroskedastisitas.Uji normalitas akan ditampilkan pada hasil yang didapatkan dengan menggunakan uji Kolmogorov-Smirnov dengan signifikansi lebih besar dari 0,05 yaitu 0,182 maka data tersebut dikatakan berdistribusi normal. Hasil multikolinearitas dapat dilihat dari nilai toleransi atau variance inflation factor (VIF). Berdasarkan hasil pengujian 
INOBIS: Jurnal Inovasi Bisnis dan Manajemen Indonesia

Volume 1, Nomor 4, September 2018

Gilang Dwi Arta; Ni Made Purnami

multikolinearitas dapat diperoleh hasil nilai VIF (Varian Inflatation Factor) tidak lebih dari 10 dan mempunyai angka tolerance tidak kurang dari 0,1, maka ini berarti dalam model regresi tidak terjadi multikolinearitas. Uji Heteroskedastisitas bertujuan untuk mengetahui apakah dalam model regresi terjadi ketidaksamaan varians dari residual satu pengamatan ke pengamatan yang lain dan pengujian ini dilakukan dengan uji glejser. Semua variabel dependen memiliki nilai signifikan > 0,05 ini berarti pada model regresi tidak terjadi gejala heteroskedasitisitas.

\section{Hasil Analisis Jalur}

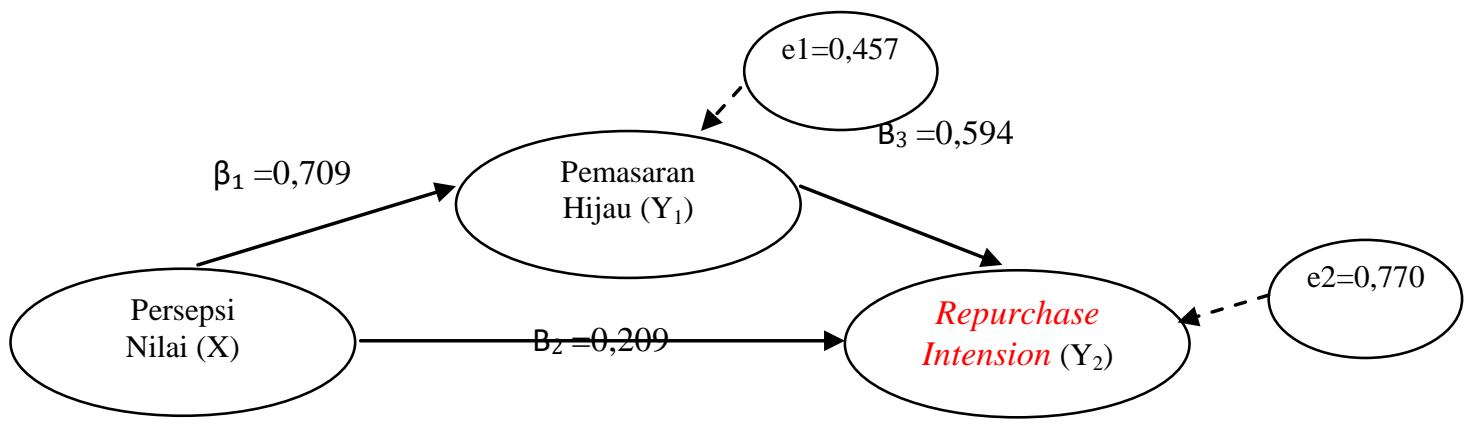

Gambar 1. Model Diagram Jalur Akhir

Persamaan yang diperoleh dari hasil analisis jalur adalah:

$\mathrm{Y}_{1}=0,709 \mathrm{X}+\mathrm{e}_{1}$

$\mathrm{Y}_{2}=0,209 \mathrm{X}+0,594 \mathrm{Y} 1+\mathrm{e}_{2}$

Berdasarkan hasil dari koefisien jalur pada hipotesis penelitian, maka dapat digambarkan hubungan kausal antar variabel persepsi nilai (X), pemasaran hijau (M) terhadap niat beli kembali (Y). Perhitungan pengaruh antar variabel dirangkum dalam Tabel 3.

Tabel 3. Pengaruh Langsung dan Pengaruh Tidak Langsung serta Pengaruh Total Persepsi Nilai (X), Pemasaran Hijau ( $\left.\mathbf{Y}_{1}\right)$, dan Repurchase Intension $\left(\mathbf{Y}_{2}\right)$

\begin{tabular}{lcccc}
\hline $\begin{array}{c}\text { Pengaruh } \\
\text { Variabel }\end{array}$ & $\begin{array}{c}\text { Pengaruh } \\
\text { Langsung }\end{array}$ & $\begin{array}{c}\text { Pengaruh Tidak Langsung }\left(\boldsymbol{\beta}_{\mathbf{1}} \mathbf{x}\right. \\
\left.\boldsymbol{\beta}_{\mathbf{3}}\right)\end{array}$ & $\begin{array}{c}\text { Pengaruh } \\
\text { Total }\end{array}$ \\
\hline$\beta_{1}$ & $\mathrm{X} \rightarrow \mathrm{Y}_{1}$ & 0,709 & - & 0,709 \\
\hline$\beta 2$ & $\mathrm{X} \rightarrow \mathrm{Y}_{2}$ & 0,209 & $(0,709 * 0,209)=0,148$ & 0,357 \\
\hline$\beta 3$ & $\mathrm{Y}_{1} \rightarrow \mathrm{Y}_{2}$ & 0,594 & - & 0,594 \\
\hline
\end{tabular}

Sumber: Hasil pengolahan data

\section{Hasil Uji Sobel}

Uji Sobel merupakan alat analisis untuk menguji signifikansi dari hubungan tidak langsung antara variabel independen dengan variabel dependen yang dimediasi oleh variabel mediator. Nilai t hitung dibandingkan dengan nilai $t$ tabel yaitu $\geq 1,96$. Jika nilai $t$ hitung lebih besar dari t tabel, maka dapat disimpulkan terjadi pengaruh mediasi. 
INOBIS: Jurnal Inovasi Bisnis dan Manajemen Indonesia

Volume 1, Nomor 4, September 2018

Gilang Dwi Arta; Ni Made Purnami

$$
\begin{aligned}
& \mathrm{S}_{\mathrm{ab}}=\sqrt{b^{2} S_{a}^{2}+a^{2} S_{b}^{2}+S_{a}^{2} S_{b}^{2}} \\
& S_{a b}=\sqrt{\left(0,594^{2}\right)(0,068)^{2}+\left(0,709^{2}\right)(0,065)^{2}+(0,065)^{2}(0,068)^{2}} \\
& S_{a b}=\sqrt{0,0038} \\
& \mathrm{~S}_{\mathrm{ab}}=0,062 \\
& \mathrm{t}=\frac{a b}{S_{a b}} \\
& \mathrm{t}=\frac{(0,594)(0,709)}{0,062} \\
& t=6,79 \\
& \mathrm{t} \text { hitung }(6,79)>\mathrm{t} \text { tabel }(1,96)
\end{aligned}
$$

Berdasarkan perhitungan, didapatkan nilai t hitung sebesar 6.79 lebih besar dari t table 1,96. Dapat disimpulkan bahwa pemasaran hijau mampu memediasi pengaruh persepsi nilai terhadap repurchase intension.

\section{Pengaruh persepsi nilai terhadap pemasaran hijau}

Hasil pengujian menunjukan bahwa nilai koefisien beta positif sebesar 0,709 dengan tingkat signifikansi sebesar $0,000<0,05$. Hasil ini mengindikasikan bahwa persepsi nilai berpengaruh positif dan signifikan terhadap pemasaran hijau yang di terapkan di Garden Villa Seminyak Bali. Hasil ini sesuai dengan hasil penelitian yang dilakukan oleh Sathiswaran et al., (2014) menemukan persepsi nilai yang dirasakan oleh konsumen mempunyai dampak positif terhadap pemasaran hijau. Hasil penelitian ini juga mendukung dukung oleh Felix (2015) dan Artha et al. (2014).

\section{Pengaruh persepsi nilai terhadap repurchase intension}

Hasil pengujian menunjukan bahwa persepsi nilai berpengaruh positif dan signifikan terhadap niat beli kembali wisatawan di Garden Villa Seminyak Bali dengan nilai signifikansi $\mathrm{t}=$ $0,009<0,05$. Hasil ini sesuai dengan hasil penelitian yang dilakukan oleh Meida et al. (2015) yang membuktikan persepsi nilai yang dinilai konsumen dapat memberikan dampak positif terhadap niat beli kembali. Artha et al. (2014) membuktikan hal yang sama niat beli kembali akan terwujud melalui peran positif dari persepsi nilai yang dipasarkan perusahaan. Sathiswaran et al. (2014) membuktikan hal yang sama dalam penelitiannya bahwa persepsi nilai mampu meningkatkan nilai perusahaan sehingga memiliki dampak positif pada niat beli kembali.

\section{Pengaruh pemasaran hijau terhadap repurchase intension}

Hasil menunjukan bahwa pemasaran hijau berpengaruh positif dan signifikan terhadap Repurchase Intension wisatawan di Garden Villa Seminyak Bali dengan nilai signifikansi $\mathrm{t}=$ $0,000<0,05$. Hasil ini sesuai dengan hasil penelitian yang dilakukan oleh Danny (2014) pemasaran hijau adalah pondasi perusahaan yang dapat memberikan pengaruh positif terhadap repurchase intension. Meida et al. (2015) menyatakan bahwa peran pemasaran hijau memberikan 
INOBIS: Jurnal Inovasi Bisnis dan Manajemen Indonesia

Volume 1, Nomor 4, September 2018

Gilang Dwi Arta; Ni Made Purnami

peluang yang baik dalam meningkatkan Repurchase Intension . Fariddeddin (2013) menyatakan hal yang sama pemasaran dengan pemasaran hijau akan memberikan pengaruh positif pada Repurchase Intension.

\section{Peran pemasaran hijau memediasi pengaruh persepsi nilai terhadap repurchase intension}

Hasil dari pengujian pengaruh tidak langsung persepsi nilai terhadap Repurchase Intension melalui pemasaran hijau menujukkan bahwa nilai t hitung sebesar 6,79 yang lebih besar dari 1,96 sehingga Hipotesis diterima. Hasil ini mengindikasikan bahwa variabel pemasaran hijau mampu memediasi pengaruh persepsi nilai terhadap repurchase intension. Hasil ini sesuai dengan penelitian yang dilakukan oleh Meida et al. (2015) menyatakan pemasaran hijau yang diterapkan perusahaan sangat dipengaruhi oleh persepsi nilai yang dirasakan konsumen pada saat menggunakan atau mengkonsumsi produk berdasarkan pemasaran hijau sebagai faktor pendukung. Sathiswaran et al. (2014) menyatakan membuktikan hal yang sama dengan adanya konsep pemasaran hijau mampu memberikan pengaruh positif hubungan persepsi nilai dengan repurchase intension. Fariddeddin (2013) menemukan hal yang sama strategi pemasaran hijau akan meningkatkan pengaruh positif persepsi nilai terhadap repurchase intension .

Efek mediasi yang terjadi adalah mediasi parsial atau partial mediation karena pada penelitian ini pengaruh variabel independen yaitu persepsi nilai terhadap variabel dependen yaitu Repurchase Intension secara langsung mendapatkan hasil yang signifikan, begitu juga secara tidak langsung melalui variabel mediasi yakni pemasaran hijau. Hasil ini dapat menjelaskan bahwa repurchase intension akan meningkat tidak hanya dengan persepsi nilai yang positif saja namun didukung oleh pemasaran hijau yang tepat.

\section{Simpulan}

Berdasarkan hasil pembahasan dapat disimpulkan sebagai berikut 1) Persepsi nilai memiliki pengaruh positif dan signifikan terhadap pemasaran hijau yang diterapkan di Garden villa Seminyak Bali. 2) Persepsi nilai memiliki pengaruh positif dan signifikan terhadap repurchase intension di Garden Villa Seminyak Bali. 3) Pemasaran hijau memiliki pengaruh positif dan signifikan terhadap repurchase intension di Garden Villa Seminyak Bali. 4) Pemasaran hijau memediasi parsial pengaruh persepsi nilai terhadap repurchase intension yang diterapkan di Garden Villa Seminyak Bali.

\section{Daftar Pustaka}

Anasti desliana, Vanessa Gafar dan Rini andari, 2013. Pengaruh program green marketing di Hotel Sangri-la Jakarta terhadap Green Consumer Behavior. Jurnal tourism and hospitality Essential Anthology, 1(4): h: 1-17

Andrew dan Franky Slamet, 2013. Pengaruh environmental behavior terhadap green purchasing behavior pada anak muda Generasi C di Jakarta. Jurnal Proceeding seminar nasional, 4(2): $h: 10-20$

Artha Wahyu Rina, Ronald, Amelia, 2014. Analisis Faktor-Faktor yang Mempengaruhi Purchase Intention melalui Social Media Marketing terhadap Produk Frozen Yogurt Sour Sally di Surabaya. Jurnal Gema Aktualita, 3(2): h: 37-44 
INOBIS: Jurnal Inovasi Bisnis dan Manajemen Indonesia

Volume 1, Nomor 4, September 2018

Gilang Dwi Arta; Ni Made Purnami

Arry Widodo, Nurafni Rubiyanti, Tiara Nandary. 2015. Factors Influencing Green Purchasing Behavior (Study on University Student in Bandung). Journal of Full Paper Proceeding, 2: h:775-785

Ashar Pratama, M. 2014. Pengaruh green perceived value, green perceived rish, dan green trust terhadap green purchase intention lampu Philips LED di Surabaya. Jurnal Ilmiah Mahasiswa Universitas Surabaya, 3(1): $h: 1-20$

Busler M and Till B.D., 2007.The match-up hypothesis:Physical Attractiveness, expertise and the role of fit on brand Attitude, Purchase Intent and Brand Belief.Journal of Advertising. 29(3): $h: 23-31$

Chen, Y.S. 2011. Green organizational identity: sources and consequence. Management decision. Vol. 49 No. 3, pp. 384-404.

Fariddeddin Allameh Haery, Dr, 2013. Effect of Green Marketing on Consumer Purchase Intentions With Regard to the Company's Image as a Mediator in the Retail Setting Case study: The Customers of Naghshe-e Jahan Sugar Company. International Journal of Academic Research in Business and Social Sciences, 3(11): h: 442-452

Felix Aprilio Rahardjo, 2015. The Roles of Green Perceived Value, Green Perceived Risk, and Green Trust towards Green Purchase Intention of Inverter Air Conditioner in Surabaya. Journal iBuss Management, 3(2): h:252-260

Hamed Dehghanan, and Ghasem Bakhshandeh, 2014. The impact of green perceived value and green perceived risk on green purchase behavior of Iranian consumers. International Journal of Management and Humanity Sciences, 3 (2), 1349-1357

Malhotra Naresh K. 2008 Marketing Research an Apllied Orientation. Second Edition. New Jersey: Prentice Hall Internasional, Inc

Mantra, Ida Bagus. 2008. Autobiografi Seorang Budayawan. Penyunting I.B. Wiana. Denpasar : Upada Sastra.

Meida Rosani Pawitaningtyas, Srikandi Kumadji dan Sunarti. 2015. Pengaruh Green Advertising terhadap citra merek serta dampaknya pada keputusan pembelian (Survei pada Pengunjung Perpustakaan Umum dan Arsip Kota Malang Konsumen Air Mineral Kemasan Botol Aqua). Jurnal Administrasi Bisnis, 25(1): h: 1-7

Mahesh, N. 2013. Consumer perceived value, attitude and purchase intention of green products. Journal institute of Management, 9(1): h: 36-43

Payne, A. 2000. "The Essence of Services Marketing". Terj. Fandy Tjiptono, Penerbit Andi, Yogyakarta.

Qinqin Liang, and Sirion Chaipoopirutana, 2014. A Study of Factors Affecting Customer's Attitude toward Intention to Purchase Green Electronic Products at an IT Mall in Beijing, China. Journal International Conference on Business, Law and Corporate Social Responsibility, 1(2): 45-49

Sathiswaran Uthamaputhran, Azlinda Shazneem binti Md Shuaib, and Nurul Hasliana binti Hamsani, 2014. The role of green marketing towards purchase intention among Malaysian customers. Journal of Entrepreneurship and Business, 2(1): h: 1-8 